\title{
ТҮРКИЯ ЕЛІНДЕГІ МӘДЕНИ-ӨРКЕНИЕТТІК ДАМУ
}

2021 жылдың тамыз айында «Қазақстанның Тұрақты Даму стратегиясы контекстінде қоғамның мәдениеті мен құндылықтарын зерттеу» ғылыми бағдарламасыауқымында Философия, саясаттану және дінтану Институтының бас директорының орынбасары Нысанбек Үлес және ғылыми қызметкерлер Д.М. Жаңабаева, А.Ж. Ержанова Түркия Республикасында іссапарда болып қайтты. Аталмыш іссапардың негізгі мақсаты мәдениет пен құндылық мәселесін зерттеу бағыттарын анықтап, тәжірибелерімен танысу болатын. Қазіргі таңда Түркия Республикасында қазіргі қоғамдағы мәдени, діни, азаматтық және ұлттық бірігейлік мәселелерін зертейтін бірқатар орталықтар мен ғылымизерттеу институттары бар.

$$
\text { Іссапар мақсатына сәйкес }
$$
бағдарлама орындаушылары Стамбул қаласындағы «Ахмет Яссауи атындағы ғылыми қордың» негізін қалаушы Исметулла Яссауимен кездесіп, ғылыми ынтымақтастық туралы меморандумға қол қойылды. Сонымен қатар, Анкара қаласында орналасқан «ANKASAM» дағдарыстық жағдайлар мен саясатты зерттеу орталығының президенті Mexмет Сайфитдин Ерол, «Ахмет Яссауи» және «Ата» қорының басшысы Намык Кемал Зиябек, «SASAM» стратегиялық зерттеу орталығының директоры Месут Эмре Каракосемен кездесу барысында заманауи түркілік қоғамдағы мәдениет пен құндылықтарды зерттеу мәселесіне қатысты пікір алмасып, соңында аталмыш орталықтармен бірлесе меморандумға қол қойылып, ғылыми байланыс орнатылды.

Жалпы қазіргі замандағы дамуға деген талпыныс заманауи әлемге тән сипаттардың бірі. Көптеген елдер ғасырлар бойы заманауи шынайылық шеңберінде ұлттық дәстүрлердің трансформациясын жүзеге асырып, дамытып, аталмыш үдеріске белсенді қосылып келеді. Заманауи қоғам негізі жағынан дәстүрлі қоғамдарға қайшы келетіні белгілі. Осы себептен қоғамның жаңа кезеңге, сатыға өтуі біршама күрделі қадамдарды қажет етеді. Жаңару үстіндегі қоғам дамуы мәселесі, соның ішінде түркілік қоғамды алатын болсақ, мұнда мәдени-өркениеттік тәсіл алынды. Бұл ретте әлеуметтік өзгерістер мәдени-өркениеттік жағдайлардың салдары ретінде қарастырылып, ал олардың ең маңызды құрамдас бөлігі рухани үдерістер есептелінеді. Әдетте, «модернизация» термині дәстүрлі аграрлық қоғамнан қазіргі индустриалды қоғамға көшу барысы ретінде түсіндіріледі.Мұнда дамушы елдер қоғамның батыстық индустриялық үлгісіне сәйкестігіне қарай сипатталады. Түркия Республикасының түрлі жаңару аспектілерін қарастыратын болсақ, оның модернизациялық парадигманы теориялық пайымдау барысындағы рөлі ерекше. XX-шы ғасырдың 20-шы жылдары басталған түркілік қоғамды реформалау тәжірибесі жеке бір мемлекеттің трансформациясы тұжырымдамасын қалыптастыру үшін өте маңызды.

Түркиядағы реформалардың бастауында тұрған, идеолог Мұстафа Кемал Ататүріктүріктердің әлемдік беделін және оларға деген құрметті жаңғырудың маңызды элементі ретінде қарастырды және ұлттық қауымдастық қана өркениеттік елдердің қатарына қосыла алатындығын алға тартты. Ол бойынша, түрік халқының ұлтшылдығы мен ұлт бірлігін нығайтатын элементтер төмендегілер болуы тиіс:

1. Ұлттық келісім туралы пакт

2. Ұлттық тәрбие 
3. Ұлттық мәдениет

4. Тіл, тарих пен мәдениет бірлігі

5. Түрік халқының өзіндік санасы

6. Рухани құндылықтар

Осы тұжырымдар аясында азаматты этникамен теңестіріліп, елдің барлық тұрғындары түріктер ретінде жарияланды. Түрік тілінен басқа тілдерге тыйым салынды. Ағарту жүйесінің барлығы ұлттық бірлектегі рухты тәрбиелеуге бағытталды. Халық арасынан шыққан өзге де қоғам белсенділері, ассимилияцияға, отаршылдыққа деген қарсылықтарын танытып, өз ұлтының мәдениетін, тілі мен ділін барынша қорғап, күрес алаңдарына шықты. Бұл тарихи-мәдени текетіресте ұлт мүддесі жолында бар күш салынды.

Қортындылай келе, аталмыш ғылыми бағдарламаны жүзеге асыру барысында шетелдік ғылыми зерттеулердің тәжірибесін ескеру қажет екендігі айқын. Қазіргі таңда қазақ және түрік елінің арасындағы әр саладағы байланысының тарихы көрсетіп отырғандай, түбірі бір екі елде халықаралық арнеадағы бірбірінің бастамаларын қолдап, түркілік интеграцияны тереңдету үшін бар күштерін салып отыр. Сонымен қатар, екі мемлекет те еуразиялық кеңістіктегі қарым-қатынас трансформациясындағы негізгі рөлді иеленіп отыр. Осыған орай, Қазақстан мен Түркия арасындағы ғылыми ынтымақтастық та үлкен интеллектуалдық нәтиже беретіндігіне сенім мол.

Динара Жаңабаева, ҚР БҒМ Философия, саясаттану және дінтану институтының жетекші ғылыми қызметкері, PhD 